\title{
INFLUENCE OF DRIP IRRIGATION MANAGEMENT ON SUGAR BEET YIELD AND SOME WATER RELATIONS AT NORTH NILE DELTA
}

\author{
Metwally, M. A. ${ }^{1}$;. A. Mady $^{2}$ and Gh. Sh. El-Atawy ${ }^{3}$
}

\section{ABSTRACT}

Two field experiments have been conducted at the experimental farm of Agriculture Faculty, Kafr El-Sheikh University, Kafr El-Sheikh Governorate $\left(31^{\circ} 05^{\prime} \mathrm{N}\right.$ latitude and $30^{\circ} 56^{\prime}$ E longitude) during the two successive growing seasons of 2009/2010 and 2010/2011 to study the overall effect of drip irrigation management on sugar beet productivity, its components and some water relations in clay soil in North Nile Delta. The treatments were arranged in a split plot design with four replicates. The main plots were assigned to three types emitters of drip irrigation system namely: built-in, simple orifice and long-path. Three irrigation regimes i.e. 10 minutes daily, 20 minutes every two days and 30 minutes every three days were allocated in the sub plots.

The main results in this study can be summarized in the following points:

1-The drip irrigation with long-path emitters (Turbo) had been achieved the highest average values of root length $(34.54$ and $34.20 \mathrm{~cm})$, root diameter (14.43 and $14.29 \mathrm{~cm}$ ), sucrose percentage (20.77 and $20.71 \%$ ), root yield (25.93 and 26.26 ton fed. $^{-1}$ ), sugar yield (5.39 and 5.44 ton fed. $\left.{ }^{1}\right)$, water productivity (18.74 and $18.84 \mathrm{~kg}$ root $\mathrm{m}^{-3}$ water consumptive use) and irrigation of water productivity $\left(15.33\right.$ and $15.32 \mathrm{~kg}_{\text {root } \mathrm{m}^{-3}}$ applied water) during 2009/2010 and 2010/2011 growing seasons, respectively.

2-The highest average values of root yield (26.16 and 26.51 ton $\mathrm{fed}^{-1}$ ), sugar yield (5.0 and 5.05 ton fed. ${ }^{-1}$ ), water productivity (17.56 and 17.64 $\mathrm{kg}$ root $\mathrm{m}^{-3}$ water consumptive use) and irrigation of water productivity (14.82 and $14.87 \mathrm{~kg}$ root $\mathrm{m}^{-3}$ applied water) had been obtained at irrigation sugar beet 20 minutes every two days in the $1^{\text {st }}$ and $2^{\text {nd }}$ seasons, respectively.

\footnotetext{
${ }^{1}$ Agric. Eng. Res. Ins., Agric. Res. Center, Giza, Egypt

${ }^{2}$ Water Management and Irrigation Systems Res. Inst., NWRC, Cairo

${ }^{3}$ Soils, Water and Environment Res. Ins., Agric. Res. Center, Giza, Egypt
} 


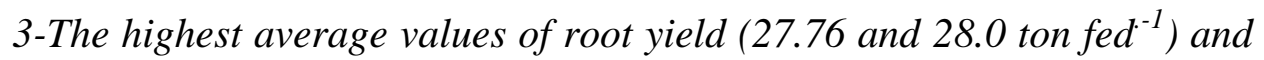
sugar yield (5.81 and 5.85 ton $\mathrm{fed}^{-1}$ ) were obtained with interaction between irrigation 20 minutes every two days and the Turbo emitter (long-path) in the $1^{\text {st }}$ and $2^{\text {nd }}$ seasons, respectively, while, the lowest average values of root yield (20.79 and 21.08 ton fed $\left.^{-1}\right)$ and sugar yield

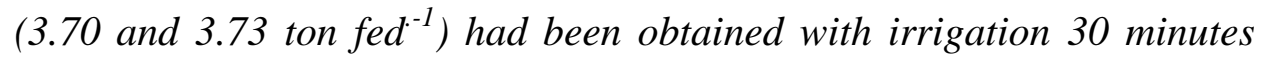
every three days using the Metalic emitter (simple-orifice) in the same growing seasons, respectively.

Keywords: Sugar beet, Simple orifice, Built-in, long-path, drip irrigation, water productivity.

\section{INTRODUCTION}

rrigation water is gradually becoming scarce not only in arid and
semi-arid regions but also in the regions where rainfall is abundant.
Egypt is a country of water scarcity due to general low precipitation, high evaporation and the temporal and spatial distribution of rainfall. Therefore, water saving and conservation is a vital and essential demand to face the water gap problem and support agricultural activities, which account for $85 \%$ of the total water consumed in semi-arid regions. Irrigation is one of the most important inputs in agricultural practices and particularly in all crops cultivation to increase crop productivity. Crop water management and its yield in different environments are very important concern in irrigation planning and maximizing yield.

Drip irrigation has been considered one of the most important obligatory irrigation systems, which keeps and management water in arid land and dry areas in addition to, it allows a large degree of water saving enabling accurate application of irrigation amounts according to crop water requirements. Under optimum management, drip irrigation system will reduce the water losses caused by evaporation and by deep percolation. Sepaskhah and Kamgar-Haghighi (1997) reported that frequent everyother-furrow irrigation at 10-days irrigation intervals used a smaller amount of irrigation water, but some yield reduction occurred. However, frequent every-other-furrow irrigation at 6-day intervals produced a similar root yield to that of every-furrow irrigation at 10-day intervals and saved about $23 \%$ of irrigation water. Crop yield may be increase if proper irrigation practices are used. Drip irrigation has been shown to reduce 
irrigation water needs compared to sprinkler or furrow systems for a variety of crops under certain circumstances, including sugar beet (Tognetti et al., 2003). Improving drought tolerance of commercial varieties of sugar beet may be a promising approach in maximizing water use efficiency (Rytter, 2005), but sugar beet breeding is long-term and expensive. An efficient way of assessing the extent and complexity of the water stress problem in sugar beet production throughout Europe may be to use crop growth modeling approach to evaluate the effects of future climatic scenarios (Richter et al., 2001). Increasing the amount of water applied gives benefits in terms of sugar beet root yield and sucrose accumulation. Drip irrigation (even applied every-other-furrow) appears to be consistently advantageous with respect to low-pressure sprinkler irrigation for sugar beet performances in semi-arid environments (Tognetti et al., 2003).

The irrigation number, amount and uniformity of water applications are used mainly to determine the efficiency of irrigation scheduling. Excessive doses of infrequently applied water will lead to high percolation losses. There is stiff competition for water by the agricultural, domestic and industrial users during the dry season, hence there is the need for farmers to conserve and make judicious use of the available water, (Adekalu and Okunade, 2006 and Ancuta et al., 2007). Kayombo et al., (2002) indicated that the crop water use efficiency has been shown to depend on irrigation amount and frequency, also, the type of irrigation system and tillage practices can influence the water use efficiency for a given irrigation frequency. Byan et al., (2002) indicated that water consumptive use (WCU) of cowpea amounted to 0.426, 0.532 and $0.639 \mathrm{~m}^{3} \mathrm{~m}^{-2}$ when irrigated by 80,100 and $120 \%$ of water calculated by class a pan method, respectively.

The main aim of the present investigation was to study the effect of drip irrigation system and irrigation intervals on sugar beet productivity, its components and some water relations in clay soil in North Nile Delta.

\section{MATERIALS AND METHODS}

Two field experiments were conducted at the experimental farm, faculty of agriculture, Kafr El-Sheikh University, Kafr El-Sheikh Governorate ( $31^{\circ} 05^{\prime} \mathrm{N}$ latitude and $30^{\circ} 56^{\prime} \mathrm{E}$ longitude), Egypt in two successive 
growing seasons of 2009/2010 and 2010/2011 to study the effect of drip irrigation system and irrigation intervals on sugar beet productivity, its components and some water relationships.

Soil samples were randomly taken from the experimental sites and prepared for analysis of both physical and chemical properties and presented in Table (1).

Table (1): Some physical and chemical properties of the experimental soil

\begin{tabular}{|c|c|c|c|c|c|c|c|c|c|}
\hline \multirow[t]{2}{*}{$\begin{array}{l}\text { Soil depth } \\
\text { (cm) }\end{array}$} & \multirow[t]{2}{*}{$\begin{array}{c}\text { Sand } \\
\%\end{array}$} & \multirow[t]{2}{*}{$\begin{array}{c}\text { Silt } \\
\%\end{array}$} & \multirow[t]{2}{*}{$\begin{array}{c}\text { Clay } \\
\%\end{array}$} & \multirow[t]{2}{*}{ Texture } & \multirow{2}{*}{$\begin{array}{c}\mathrm{EC} \mathrm{dSm}^{-1} \\
\text { (1:5 Soil : } \\
\text { Water } \\
\text { extract) }\end{array}$} & \multirow[t]{2}{*}{$\begin{array}{c}\text { pH 1: } 2.5 \\
\text { Soil: Water } \\
\text { suspension }\end{array}$} & \multicolumn{3}{|c|}{$\begin{array}{c}\text { Available } \\
\text { nutrients } \\
\mathrm{Mg} \mathrm{kg}^{-1} \text { soil }\end{array}$} \\
\hline & & & & & & & $\mathbf{N}$ & $\mathbf{P}$ & $\mathbf{K}$ \\
\hline $0-15$ & 33.0 & 28.6 & 38.4 & Clay loam & 3.32 & 7.80 & & & \\
\hline $15-30$ & 33.4 & 28.4 & 38.2 & Clay loam & 3.58 & 7.60 & & & \\
\hline $30-45$ & 33.2 & 28.5 & 38.3 & Clay loam & 3.45 & 7.70 & 22 & 1.6 & 18 \\
\hline $45-60$ & 33.0 & 28.6 & 38.4 & Clay loam & 3.49 & 7.75 & & & \\
\hline
\end{tabular}

Field capacity, permanent wilting point and bulk density were measured according to Klute (1986). Available soil moisture was calculated as the difference between the field capacity and permanent wilting point and presented in Table (2).

Table (2): Average values of field capacity and bulk density for the two growing seasons.

\begin{tabular}{|l|c|c|c|c|c|c|}
\hline Soil depth & $\begin{array}{c}\text { Bulk density } \\
\mathbf{( k g ~ m}^{-3} \mathbf{)}\end{array}$ & $\begin{array}{c}\text { Field } \\
\text { capacity } \\
\text { \% }\end{array}$ & $\begin{array}{c}\text { Per-wilting } \\
\text { point \% }\end{array}$ & $\begin{array}{c}\text { Available } \\
\text { water \% }\end{array}$ & $\begin{array}{c}\text { EC of } \\
\text { irrigation } \\
\text { water }\end{array}$ & $\begin{array}{c}\text { Readily } \\
\text { available } \\
\text { water \% }\end{array}$ \\
\hline $0-15$ & 1120 & 40.50 & 20.64 & 19.86 & & 12.91 \\
$15-30$ & 1260 & 38.02 & 19.04 & 18.98 & 0.64 & 12.34 \\
$30-45$ & 1340 & 36.25 & 18.22 & 18.03 & $\mathrm{dSm}^{-1}$ & 11.72 \\
$45-60$ & 1380 & 35.75 & 17.91 & 17.84 & & 11.60 \\
\hline
\end{tabular}

\section{Experimental layout:}

The experimental design was laid out in split plot design with four replicates in both growing seasons. 
The main treatments were drip irrigation system with three types of emitters as follows:

$$
\begin{aligned}
& \text { A- Simple orifice (Metalic) (M). } \\
& \text { B- Built-in (GR). } \\
& \text { C- long-path (Turbo). }
\end{aligned}
$$

The sub treatments were irrigation regimes as follows:

1- 10 minutes daily.

2- 20 minutes every two days.

3- 30 minutes every three days.

Each experimental block was $2 \mathrm{~m}$ in width (across the crop rows) and 30 $\mathrm{m}$ in length (along the crop rows). The irrigation network consisted of a main delivery pipe (PE, $32 \mathrm{~mm}$ ) and the secondary ones (PE, $25 \mathrm{~mm}$ ). The drip laterals were of $16 \mathrm{~mm}$ inside diameter, polyethylene pipe with in line drippers of $4 \mathrm{~L} \mathrm{~h}^{-1}$, at $30 \mathrm{~cm}$ apart the laterals were located $60 \mathrm{~cm}$ apart, one or two laterals for each plants row. Irrigation water was filtered through gravel filters and refiltered through screen filters.

Multigerm seeds of sugar beet (Rao poly cv.) were sown by hand in hills on $15^{\text {th }}$ August 2009 and $19^{\text {th }}$ August 2010, at row spacing of $60 \mathrm{~cm}$ and in- row spacing of $25 \mathrm{~cm}$. Plants were thinned to one plant per hill after 40 days from sowing (at 4-6 leaves stage). Fertilizers were added according to the technical recommendation of the Egyptian Ministry of Agriculture at rates of $90 \mathrm{~kg} \mathrm{~N}, 15 \mathrm{~kg} \mathrm{P}_{2} \mathrm{O}_{5}$ and $100 \mathrm{~kg} \mathrm{k}_{2} \mathrm{SO}_{4} \mathrm{fed}^{-1}{ }^{-1},(1$ feddan $=0.42$ hectar). Phosphorus fertilizer was broadcast at seedbed preparation in the form of calcium super phosphate $\left(\begin{array}{lll}15.5 \% & \mathrm{P}_{2} \mathrm{O}_{5}\end{array}\right)$. Nitrogen fertilizer in the form of ammonium nitrate $(33.5 \% \mathrm{~N})$ was added in two equal doses before the first irrigation (after thinning) and before the second irrigation. Potassium fertilizer was applied by topdressing in one application of potassium sulphate $\left(48 \% \mathrm{k}_{2} \mathrm{O}\right)$ before the first irrigation. All agricultural practices for sugar beet were done as recommended by the Egyptian Ministry of Agricultural and Land Reclamation, except the factors under study. The harvesting date was February $25^{\text {th }}$ and $28^{\text {th }}$ (after 190 days from sowing) for two growing seasons. 


\section{-Crop and water parameters:}

\section{-Irrigation water applied (IWA):}

The amount of irrigation water applied for drip irrigation system at each irrigation was measured by flowmeter and calculated according to Keller and Karmeli (1974) as follows:

$$
\mathrm{IWA}=\frac{\mathrm{ETo} \cdot \mathrm{Kc} \cdot \mathrm{Kr} \cdot \mathrm{II}}{\mathrm{Ea}}+\mathrm{LR}
$$

Where:

IWA $=$ Irrigation water applied, mm.

ETo $=$ Reference evapotranspiration, $m m \cdot d_{a y}{ }^{-1}$.

$\mathrm{Kc} \quad=$ Crop coefficient, dimensiondess.

$\mathrm{Kr} \quad=$ Reduction factor (Keller and Karmeli, 1974).

II = Irrigation intervals, days.

$\mathrm{Ea} \quad=$ Irrigation efficiency, $\%=\mathrm{K}_{1} \times \mathrm{K}_{2}=0.80$.

$\mathrm{K}_{1} \quad=$ Emitter uniformity coefficient $=0.90$.

$\mathrm{K}_{2}=$ Drip irrigation efficiency coefficient $=0.90$.

$\mathrm{LR}=$ Leaching requirements (10\% of Etc).

Reference evapotranspiration (ETo) were estimated using penmanMonteith, as calculated by Allen et al. (1998).

-Water Consumptive Use (CU):

Soil moisture content was determined before and after each irrigation to calculate water consumptive use according to the following equation (Hansen et al., 1979).

$$
\mathrm{SMD}=\mathrm{Cu}=\sum_{i=1}^{\mathrm{l}=4} \mathrm{D}_{1} \times \mathrm{D}_{\mathrm{b} 1} \times \frac{\mathrm{PW}_{2}-\mathrm{PW}_{1}}{100}
$$

Where:

SMD $=$ Soil moisture depletion in the effective root zone, $\mathrm{cm}$.

$\mathrm{CU}=$ Water consumptive use, $\mathrm{cm}$.

$\mathrm{D}_{1} \quad=$ Soil layer depth, $\mathrm{cm}$ (root depth).

$\mathrm{D}_{\mathrm{b} 1} \quad=$ Soil bulk density for this depth.

$\mathrm{PW}_{1}=$ Soil moisture percentage before irrigation (\%, d.b.).

$\mathrm{PW}_{1}=$ Soil moisture percentage, 48 hours after irrigation ((\%, d.b.).

I $=$ Number of soil layers each $(15 \mathrm{~cm})$ depth. 


\section{-Water productivity (WP):}

Water productivity was calculated according to Ali et al., (2007) as follows:

$$
\mathrm{WP}=\mathrm{GY} / \mathrm{ET}
$$

Where:

Gy $=$ Root yield, $\mathrm{kg}$ fed..$^{-1}$.

$\mathrm{ET}=$ Total water consumptive use of the growing season, $\mathrm{m}^{3}$ fed. ${ }^{-1}$.

\section{-Productivity of irrigation water (PIW)}

Productivity of irrigation water was calculated according to (Ali et al., 2007).

Where:

$$
\mathrm{PIW}=\mathrm{GY} / \mathrm{IW}
$$

Gy $=$ Root yield, $\mathrm{kg}$ fed. ${ }^{-1}$.

IW =Irrigation water applied, $\mathrm{m}^{3}$ fed. ${ }^{-1}$.

\section{-Crop parameters:}

\section{-Root length and diameter.}

At harvest time, (190 days after sowing) random sample of ten plants, were chosen from each plot to determine some plant parameters of sugar beet growth (i.e. root diameter and root length $(\mathrm{cm})$, as well as, root weight $(\mathrm{Kg})$. Also, some characters of sugar beet roots quality have been measured and calculated such as sucrose (\%) and the purity (\%) were measured at Delta sugar Company Limited Laboratories at El-Hammol, Kafr El-Sheikh Governorate.

\section{-Yield and its components of sugar beet:}

The root yield (ton.fed. ${ }^{-1}$ ), sucrose percentage and juice purity (\%) were determined for sugar beet from the three central furrows of the plots by the Delta sugar Company Limited Laboratories at Kafr El-Sheikh Governorate.

The gross sugar content was calculated as follows:

Gross sugar $=$ sucrose percentage $\times$ root yield $\left(\right.$ ton fed. $\left.{ }^{-1}\right)$.

\section{-Plant analysis:}

Samples of sugar beet roots were taken to determine their composition before harvesting. The root samples were dried at $70^{\circ} \mathrm{C}$ for 24 hours, 
ground and then wet digested by sulfuric and perchloric acids according to the method described by Chapman and Pratt (1961). Sucrose percentage and root juice purity were determined in fresh root at harvesting by an automatic sugar polarimeter as described by Mc Ginnus (1971).

\section{-Statistical analysis:}

The obtained data were statistically analyzed by analysis of variance. The data of the two seasons showed nearly the same trend, Thus, combined analysis was done according to Gomez and Gomez (1984) .Means of the treatment were compared by the least significant difference (LSD) at 5\% level of significance which developed by Waller and Duncan (1969).

\section{RESULTS AND DISCUSSION}

\section{1-Sugar beet yield and quality:}

\section{a- Root and sugar yield:}

Data in Table 3 show that root and sugar yields of sugar beet were significantly affected by type of emitter and irrigation regimes during two growing seasons of 2009/2010 and 2010/2011. The Turbo emitter (long-path) achieved the highest average values of root yield (25.93and 26.26 ton fed. $^{-1}$ ) and sugar yield (5.39 and 5.44 ton fed. $^{-1}$ ), while, the lowest average values of root yield (22.55 and 22.90 ton fed. $^{-1}$ ) and sugar yield (3.86 and 3.90 ton fed..$^{-1}$ ) had been obtained with the Metalic emitter (simple-orifice) in the $1^{\text {st }}$ and $2^{\text {nd }}$ growing seasons, respectively.

Data also indicate that there are significant differences between irrigation regimes treatments in root and sugar yield for two growing seasons. The treatments which were irrigated 20 minutes every two days recorded the maximum average values of root yield (26.16 and 26.51 ton fed. $\left.{ }^{-1}\right)$ and

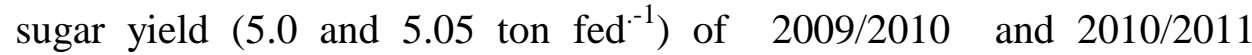
growing seasons, respectively. Meanwhile, the treatments which were irrigated 30 minutes every three days gave the minimum average values of root yield ( 22.82 and 23.22 ton fed. $^{-1}$ ) and sugar yield (4.46 and 4.52 ton fed. $\left.{ }^{-1}\right)$ in the two growing seasons, respectively. However, the root yield increased by (7.83 and $7.81 \%)$ and sugar yield increased by (10.6 and $10.5 \%$ ) as a result of irrigation 20 minutes every two days instead of 
irrigation 10 minutes daily in the $1^{\text {st }}$ and the $2^{\text {nd }}$ season, respectively. Interaction between type of drippers and irrigation intervals had a highly significant effect on the root and sugar yield.

Table 3: Mean values of sugar beet yield, gross sugar yield and sucrose percentage as affected by drip irrigation system and irrigation regimes during 2009/2010 and 2010/2011 seasons.

\begin{tabular}{|c|c|c|c|c|c|c|c|}
\hline \multirow{2}{*}{$\begin{array}{l}\text { Type of } \\
\text { drippers }\end{array}$} & \multirow{2}{*}{$\begin{array}{c}\text { Irrigation } \\
\text { regimes, min. }\end{array}$} & \multicolumn{2}{|c|}{$\begin{array}{c}\text { Sugar beet } \\
\text { yield , ton fed } \text { fed }^{-1}\end{array}$} & \multicolumn{2}{|c|}{$\begin{array}{c}\text { Gross sugar, ton } \\
\text { fed }^{-1} \\
\end{array}$} & \multicolumn{2}{|c|}{ Sucrose, \% } \\
\hline & & $\begin{array}{l}2009 / \\
2010 \\
\end{array}$ & $\begin{array}{r}2010 / \\
2011\end{array}$ & $\begin{array}{l}2009 / \\
2010 \\
\end{array}$ & $\begin{array}{l}2010 / \\
2011\end{array}$ & $\begin{array}{c}2009 / \\
2010 \\
\end{array}$ & $\begin{array}{r}2010 / \\
2011 \\
\end{array}$ \\
\hline \multirow{3}{*}{ Biult-in } & 10 daily & 24.68 & 24.90 & 4.63 & 4.66 & 18.75 & 18.70 \\
\hline & 20/ 2 days & 26.35 & 26.80 & 5.05 & 5.12 & 19.15 & 19.10 \\
\hline & 30/ 3 days & 23.25 & 23.78 & 4.54 & 4.62 & 19.52 & 19.44 \\
\hline \multirow{3}{*}{$\begin{array}{l}\text { Simple- } \\
\text { orifice }\end{array}$} & 10 daily & 22.49 & 22.90 & 3.73 & 3.78 & 16.60 & 16.50 \\
\hline & 20/ 2 days & 24.37 & 24.72 & 4.15 & 4.18 & 17.02 & 16.92 \\
\hline & 30/ 3 days & 20.79 & 21.08 & 3.70 & 3.73 & 17.80 & 17.70 \\
\hline \multirow{3}{*}{ Long-path } & 10 daily & 25.60 & 25.98 & 5.20 & 5.26 & 20.31 & 20.24 \\
\hline & 20/ 2 days & 27.76 & 28.00 & 5.81 & 5.85 & 20.92 & 20.89 \\
\hline & 30/ 3 days & 24.43 & 24.80 & 5.15 & 5.21 & 21.08 & 21.00 \\
\hline \multicolumn{2}{|c|}{ L.S.D at 0.05} & 0.079 & 0.203 & 0.019 & 0.058 & 0.030 & $\mathbf{0 . 0 8 8}$ \\
\hline \multirow{3}{*}{$\begin{array}{c}\text { Mean of } \\
\text { drippers } \\
\text { types }\end{array}$} & Biult-in & 24.76 & 25.16 & 4.74 & 4.80 & 19.14 & 19.08 \\
\hline & Simple- orifice & 22.55 & 22.90 & 3.86 & 3.90 & 17.14 & 17.04 \\
\hline & Long-path & 25.93 & 26.26 & 5.39 & 5.44 & 20.77 & 20.71 \\
\hline \multicolumn{2}{|c|}{ L.S.D at 0.05} & 0.114 & 0.063 & 0.031 & 0.025 & 0.066 & 0.075 \\
\hline \multirow{3}{*}{$\begin{array}{c}\text { Mean of } \\
\text { irrigation } \\
\text { regimes }\end{array}$} & 10 daily & 24.26 & 24.59 & 4.52 & 4.57 & 18.55 & 18.48 \\
\hline & 20/ 2 days & 26.16 & 26.51 & 5.00 & 5.05 & 19.03 & 18.97 \\
\hline & 30/ 3 days & 22.82 & 23.22 & 4.46 & 4.52 & 19.60 & 19.38 \\
\hline \multicolumn{2}{|c|}{ L.S.D at 0.05} & 0.170 & 0.200 & 0.046 & 0.060 & 0.096 & 0.121 \\
\hline
\end{tabular}

The results also indicate that the highest average values of root yield (27.76 and 28.0 ton $\mathrm{fed}^{-1}$ ) and sugar yield (5.81 and 5.85 ton $^{-e^{-1}}$ ) were obtained with the Turbo emitter (long-path) and irrigation 20 minutes every two days in the $1^{\text {st }}$ and $2^{\text {nd }}$ seasons, respectively, while, the lowest average values of root yield (20.79 and 21.08 ton fed..$^{-1}$ ) and sugar yield 
(3.70 and 3.73 ton fed $^{-1}$ ) had been obtained with the Metalic emitter (simple-orifice) and irrigation 30 minutes every three days in the $1^{\text {st }}$ and $2^{\text {nd }}$ growing seasons, respectively.

Increasing in sugar beet yield may be due to increasing the available soil moisture and supplying sugar beet plants with more nutrients which in turn produced high vegetative growth as well as carbohydrates translocation process from the vegetative growth to roots and this increase sugar beet yield. These results agreed with those obtained by Isoda el al. (2007) Abo-Shady et al. (2010), El-Nemr (2010), Hassanli et al. (2010) and Baigy et al. (2012).

\section{b- Sucrose percentage:}

Data presented in Table 3 indicate that sucrose percentage significantly influenced type of emitter and irrigation intervals during growing seasons of 2009/2010 and 2010/2011. The highest average values of sucrose percentage (20.77 and $20.71 \%$ ) were recorded with the Turbo emitter (long-path) during 2009/2010 and 2010/2011 growing seasons, respectively. While, the lowest average values of sucrose percentage (17.14 and 17.04\%) were obtained with the Metalic emitter (simpleorifice) for the same seasons.

On the other hand, the treatments which were irrigated 30 minutes every three days attained the maximum average values (19.60 and $19.38 \%$ ) of sucrose percentage compared with the other treatments for two growing seasons. These obtained results were in good agreement with those of Ibrahim et al. (2002), Rytter (2005), Ghadami Firouz Abadi and Mirzaei (2006), Isoda et al. (2007) and Hassanli et al. (2010).

\section{c- Root length and diameter:}

Data of sugar beet length and diameter, which significantly affected by type of emitter and irrigation intervals for growing seasons 2009/2010 and 2010/2011, are presented in Table 4.

The maximum average values of root length $(34.54$ and $34.20 \mathrm{~cm})$ and root diameter $(14.43$ and $14.29 \mathrm{~cm})$ were realized with the Turbo emitter (long-path) for 2009/2010 and 2010/2011 growing seasons, respectively. Whereas, the minimum average values of root length (31.36 and 31.10 $\mathrm{cm})$ and root diameter $(12.64$ and $12.48 \mathrm{~cm}$ ) were fulfilled with the Metalic emitter (simple-orifice) for two growing seasons, respectively. 
Data also manifest that irrigating sugar beet crop 30 minutes every three days gave the highest average values of root length $(35.0$ and $34.58 \mathrm{~cm})$ and the minimum average values of root diameter $(12.29$ and $12.06 \mathrm{~cm})$ compared with the other irrigation regimes. However, the irrigation regime 10 minutes daily accomplished the minimum average values of root length (31.41 and $31.12 \mathrm{~cm}$ ) and maximum average values of root diameter (14.19 and $14.03 \mathrm{~cm}$ ) for two growing seasons, respectively. In case of irrigation through short regimes, the water is still available in the upper layers of the soil consequently, the plant roots do not grow vertically but the root diameter becomes more. On the century, in case of increasing irrigation regimes the root length increases to get the water requirements for plants from deeper layers but the root diameter is less.

In the present study indicated that, proportionately; higher root length and lower root diameter might be possible by the application of relatively low amounts of irrigation water. Similar observations were reported by ElMaghraby et al. (2008), Abo-Shady et al. (2010) and Baigy et al. (2012).

Table (4): Mean values of root length and root diameter as affected by drip irrigation systems and irrigation regimes in 2009/2010 and 2010/2011 seasons.

\begin{tabular}{|c|c|c|c|c|c|}
\hline \multirow{2}{*}{$\begin{array}{l}\text { Type of } \\
\text { drippers }\end{array}$} & \multirow{2}{*}{$\begin{array}{l}\text { Irrigation } \\
\text { regimes, minute. }\end{array}$} & \multicolumn{2}{|c|}{ Root length, cm } & \multicolumn{2}{|c|}{ Root diameter, cm } \\
\hline & & $\begin{array}{c}2009 / \\
2010\end{array}$ & $\begin{array}{c}2010 / \\
2011\end{array}$ & $\begin{array}{c}2009 / \\
2010\end{array}$ & $\begin{array}{c}2010 / \\
2011\end{array}$ \\
\hline \multirow{3}{*}{ Biult-in } & 10 daily & 31.82 & 31.62 & 14.10 & 13.92 \\
\hline & 20/ 2 days & 33.92 & 33.57 & 13.92 & 13.86 \\
\hline & 30/ 3 days & 35.60 & 35.10 & 12.00 & 11.76 \\
\hline \multirow{3}{*}{$\begin{array}{l}\text { Simple- } \\
\text { orifice }\end{array}$} & 10 daily & 29.80 & 29.50 & 13.16 & 13.02 \\
\hline & 20/ 2 days & 31.46 & 31.30 & 12.90 & 12.80 \\
\hline & 30/3 days & 32.82 & 32.50 & 11.86 & 11.62 \\
\hline \multirow{3}{*}{ Long-path } & 10 daily & 32.62 & 32.25 & 15.30 & 15.16 \\
\hline & 20/ 2 days & 34.43 & 34.20 & 14.98 & 14.90 \\
\hline & 30/3 days & 36.57 & 36.15 & 13.01 & 12.81 \\
\hline \multicolumn{2}{|c|}{ L.S.D at 0.05} & 0.240 & 0.265 & 0.109 & 0.065 \\
\hline \multirow{3}{*}{$\begin{array}{c}\text { Mean of } \\
\text { drippers } \\
\text { types }\end{array}$} & Biult-in & 33.78 & 33.43 & 13.34 & 13.18 \\
\hline & Simple- orifice & 31.36 & 31.10 & 12.64 & 12.48 \\
\hline & Long-path & 34.54 & 34.20 & 14.43 & 14.29 \\
\hline \multicolumn{2}{|c|}{ L.S.D at 0.05} & 0.126 & 0.116 & 0.065 & 0.070 \\
\hline \multirow{3}{*}{$\begin{array}{l}\text { Mean of } \\
\text { irrigation } \\
\text { regimes }\end{array}$} & 10 daily & 31.41 & 31.12 & 14.19 & 14.03 \\
\hline & 20/ 2 days & 33.27 & 33.02 & 13.93 & 13.85 \\
\hline & 30/ 3 days & 35.00 & 34.58 & 12.29 & 12.06 \\
\hline \multicolumn{2}{|c|}{$\begin{array}{l}\text { L.S.D at } 0.05 \\
\end{array}$} & 0.263 & 0.275 & 0.126 & 0.110 \\
\hline
\end{tabular}




\section{2- Water relations:}

\section{a- Irrigation Water Applied (IWA):}

Amounts of irrigation water applied $\left(\mathrm{m}^{3}\right.$ fed. $\left.{ }^{-1}\right)$ and water consumptive use $\left(\mathrm{m}^{3} \mathrm{fed}^{-1}\right)$ as affected by type of emitter and irrigation regimes during 2009/2010 and 2010/2011 seasons were presented in Table 5. The average total amounts of irrigation water applied were 1820, 1795 and $1692 \mathrm{~m}^{3}$ fed. $^{-1}$ with built-in, Metallic (simple- orifice) and Turbo (longpath) emitters, respectively in 2009/2010 growing season, whereas, it were 1836, 1810 and $1714 \mathrm{~m}^{3}$ fed. $^{-1}$ in 2010/2011 season for the same irrigation system. It can be concluded that the lowest values of irrigation water were applied with the Turbo (long-path) emitter but, the highest average amounts of irrigation water were applied with the built-in emitter for two growing seasons.

\section{b- Water consumptive use "CU" in $\mathbf{m}^{3}$ fed. ${ }^{-1}$ :}

Average values of water consumptive use of sugar beet in 2009/2010 and 2010/2011 growing seasons were significantly affected by type of emitter and irrigation intervals as show in Table $\mathbf{5}$.

It is clear that the minimum average values of CU (1384 and $1394 \mathrm{~m}^{3}$ fed..$^{-1}$ ) were obtained with the Turbo emitter while, the maximum average values of CU (1584 and $1596 \mathrm{~m}^{3}$ fed. $^{-1}$ ) were recorded with the built-in emitter in the two growing seasons, respectively. On the other hand, the obtained average values of CU were 1518, 1498 and $1488 \mathrm{~m}^{3} \mathrm{fed}^{-1}$ in the $1^{\text {st }}$ season but, it were 1529,1510 and $1502 \mathrm{~m}^{3} \mathrm{fed}^{-1}$ in the $2^{\text {nd }}$ season at using irrigation regimes 10 minutes daily, 20 and 30 minutes every two and three days, respectively.

Results reveal that water consumptive use increased with decreased intervals of irrigation, these obtained results were in good agreement with those of Rinaldi and Vonella (2006), Isoda (2007) and Hassanli et al. (2010). 
Table (5): Water applied and water consumptive use as affected by drip irrigation systems and irrigation regimes during 2009/2010 and 2010/2011 seasons.

\begin{tabular}{|c|c|c|c|c|c|c|c|c|c|}
\hline \multirow{3}{*}{$\begin{array}{l}\text { Type of } \\
\text { drippers }\end{array}$} & \multirow{3}{*}{$\begin{array}{c}\text { Irrigation } \\
\text { regimes, } \\
\text { minute. }\end{array}$} & \multirow[t]{3}{*}{ 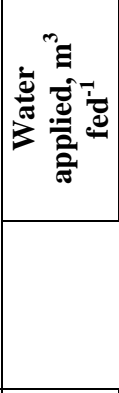 } & \multirow{3}{*}{ 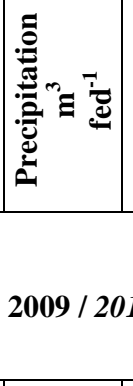 } & \multirow{3}{*}{ 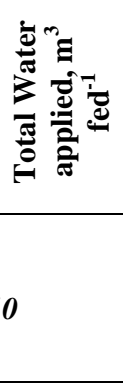 } & \multirow[t]{3}{*}{ 离 } & \multirow{3}{*}{$2010 / 201$} & \multirow{3}{*}{ 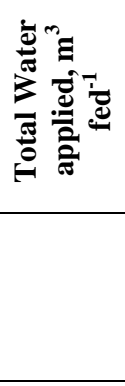 } & \multicolumn{2}{|c|}{$\begin{array}{c}\text { Water } \\
\text { consumptive } \\
\text { use, } \\
\text { m }^{3} \text { fed }^{-1} \\
\end{array}$} \\
\hline & & & & & & & & $\begin{array}{c}2009 \\
/\end{array}$ & $\begin{array}{c}2010 \\
/\end{array}$ \\
\hline & & & & & & & & 2010 & 2011 \\
\hline \multirow{3}{*}{ Biult-in } & 10 daily & 1690 & 130 & 1820 & 1726 & 110 & 1836 & 1605 & 1616 \\
\hline & 20/ 2 days & 1690 & 130 & 1820 & 1726 & 110 & 1836 & 1591 & 1605 \\
\hline & 30/ 3 days & 1690 & 130 & 1820 & 1726 & 110 & 1836 & 1556 & 1568 \\
\hline \multirow{3}{*}{$\begin{array}{l}\text { Simple- } \\
\text { orifice }\end{array}$} & 10 daily & 1665 & 130 & 1795 & 1700 & 110 & 1810 & 1537 & 1550 \\
\hline & 20/ 2 days & 1665 & 130 & 1795 & 1700 & 110 & 1810 & 1521 & 1534 \\
\hline & 30/ 3 days & 1665 & 130 & 1795 & 1700 & 110 & 1810 & 1551 & 1568 \\
\hline \multirow{3}{*}{ Long-path } & 10 daily & 1262 & 130 & 1692 & 1604 & 110 & 1714 & 1412 & 1420 \\
\hline & 20/ 2 days & 1262 & 130 & 1692 & 1604 & 110 & 1714 & 1382 & 1392 \\
\hline & 30/ 3 days & 1262 & 130 & 1692 & 1604 & 110 & 1714 & 1357 & 1370 \\
\hline \multicolumn{2}{|c|}{ L.S.D at 0.05} & & - & - & - & - & - & 12.23 & 2.48 \\
\hline \multirow{3}{*}{$\begin{array}{c}\text { Mean of } \\
\text { drippers } \\
\text { types }\end{array}$} & Biult-in & 1690 & 130 & 1820 & 1726 & 110 & 1836 & 1584 & 1596 \\
\hline & $\begin{array}{c}\text { Simple- } \\
\text { orifice }\end{array}$ & 1665 & 130 & 1795 & 1700 & 110 & 1810 & 1536 & 1551 \\
\hline & Long-path & 1262 & 130 & 1692 & 1604 & 110 & 1714 & 1384 & 1394 \\
\hline \multicolumn{2}{|c|}{ L.S.D at 0.05} & & - & - & - & - & - & 8.06 & 4.41 \\
\hline \multirow{3}{*}{$\begin{array}{c}\text { Mean of } \\
\text { irrigation } \\
\text { regimes } \\
\end{array}$} & 10 daily & 1639 & 130 & 1769 & 1677 & 110 & 1787 & 1518 & 1529 \\
\hline & 20/ 2 days & 1639 & 130 & 1769 & 1677 & 110 & 1787 & 1498 & 1510 \\
\hline & 30/ 3 days & 1639 & 130 & 1769 & 1677 & 110 & 1787 & 1488 & 1502 \\
\hline \multicolumn{2}{|c|}{ L.S.D at 0.05} & & - & - & - & - & - & 14.80 & 6.47 \\
\hline
\end{tabular}

\section{c- Water productivity (WP):}

Water productivity (WP) expressed in $\mathrm{kg}$ of roots $\mathrm{m}^{-3}$ of water consumed and productivity of irrigation water (PIW) in $\mathrm{kg}$ of roots $\mathrm{m}^{-3}$ of irrigation water applied in two growing seasons are presented in Table 6. 
Water productivity determines the capacity of the plants to convert the consumed water to stop yield. The WP and PIW of sugar beet could be evaluated by both root and sugar yields. The obtained results show that the Turbo emitter (long -path) gave the highest average values of WP

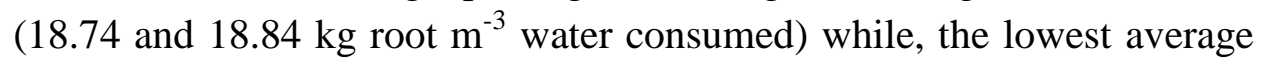
of WP (15.33 and $15.32 \mathrm{~kg}$ root $\mathrm{m}^{-3}$ water consumed) were recorded with the Metalic emitter (simple-orifice) during 2009/2010 and 2010/2011 growing seasons, respectively. The WP values increased by 19.9 and 27.7 $\%$ when the Turbo emitter (long-path) was used instead of the built-in emitters and Metalic (simple-orifice) emitters, respectively during the $1^{\text {st }}$ season.

The results also indicated that the obtained average values of WP were $16.05,17.56$ and $15.69 \mathrm{~kg}$ root $\mathrm{m}^{-3}$ water consumed with irrigation intervals of 10, 20 and 30 minutes daily, every two and three days, respectively in the $1^{\text {st }}$ season. Similar observations were reported by Rytter (2005) and Baigy et al. (2012).

\section{d- Productivity of irrigation water (PIW):}

Results presented in Table 6 indicate that the highest average values of PIW 15.33 and $15.32 \mathrm{~kg}$ root $\mathrm{m}^{-3}$ of irrigation water applied were obtained with using the Turbo emitter (long -path) in the $1^{\text {st }}$ and $2^{\text {nd }}$ growing seasons, respectively. While, the lowest ones, 12.56 and 12.65 $\mathrm{kg}$ root $\mathrm{m}^{-3}$ of irrigation water applied were attained from irrigated by using the Metalic emitter (simple-orifice) during the $1^{\text {st }}$ and the $2^{\text {nd }}$ seasons, respectively. These results could be attributed to the significant differences among sugar beet yield, evapotranspiration and water applied values.

Concerning the effect of irrigation interval on the PIW, as shown in Table 6 , results reveal that irrigating sugar beet crop 20 minutes every two days accomplished the maximum average values of PIW (14.82 and $14.87 \mathrm{~kg}$ root $\mathrm{m}^{-3}$ of irrigation water applied), whereas the minimum average values of PIW (12.93 and $13.02 \mathrm{~kg}$ root $\mathrm{m}^{-3}$ of irrigation water applied) in the two growing seasons were obtained with irrigation interval of 30 minutes every three days. 
Table (6): Water productivity (WP) and productivity of irrigation water (PIW) as affected by drip irrigation systems and irrigation regimes during 2009/2010 and 2010/2011 seasons.

\begin{tabular}{|c|c|c|c|c|c|}
\hline \multirow{2}{*}{$\begin{array}{l}\text { Type of } \\
\text { drippers }\end{array}$} & \multirow{2}{*}{$\begin{array}{c}\text { Irrigation regimes, } \\
\text { minute. }\end{array}$} & \multicolumn{2}{|c|}{ WP, Kg root. $\mathrm{m}^{-3}$} & \multicolumn{2}{|c|}{ PIW, Kg root. $\mathrm{m}^{-3}$} \\
\hline & & $\begin{array}{r}2009 / \\
2010\end{array}$ & $\begin{array}{l}2010 / \\
2011\end{array}$ & $2009 / 2010$ & $\begin{array}{l}2010 / \\
2011\end{array}$ \\
\hline \multirow{3}{*}{ Biult-in } & 10 daily & 15.38 & 15.41 & 13.56 & 13.56 \\
\hline & 20/ 2 days & 16.56 & 16.70 & 14.48 & 14.60 \\
\hline & 30/ 3 days & 14.94 & 15.17 & 12.77 & 12.95 \\
\hline \multirow{3}{*}{$\begin{array}{l}\text { Simple- } \\
\text { orifice }\end{array}$} & 10 daily & 14.63 & 14.77 & 12.53 & 12.65 \\
\hline & 20/ 2 days & 16.02 & 16.11 & 13.58 & 13.66 \\
\hline & 30/ 3 days & 13.40 & 13.44 & 11.58 & 11.65 \\
\hline \multirow{3}{*}{ Long-path } & 10 daily & 18.13 & 18.30 & 15.13 & 15.16 \\
\hline & 20/ 2 days & 20.09 & 20.11 & 16.41 & 16.34 \\
\hline & 30/ 3 days & 18.00 & 18.10 & 14.44 & 14.47 \\
\hline \multicolumn{2}{|c|}{ L.S.D at 0.05} & 0.123 & 0.085 & 0.056 & 0.079 \\
\hline \multirow{3}{*}{$\begin{array}{c}\text { Mean of } \\
\text { drippers } \\
\text { types }\end{array}$} & Biult-in & 15.63 & 15.76 & 13.60 & 13.70 \\
\hline & Simple- orifice & 14.68 & 14.77 & 12.56 & 12.65 \\
\hline & Long-path & 18.74 & 18.84 & 15.33 & 15.32 \\
\hline \multicolumn{2}{|c|}{ L.S.D at 0.05} & 0.079 & 0.059 & 0.056 & 0.033 \\
\hline \multirow{3}{*}{$\begin{array}{l}\text { Mean of } \\
\text { irrigation } \\
\text { regimes }\end{array}$} & 10 daily & 16.05 & 16.16 & 13.74 & 13.79 \\
\hline & 20/ 2 days & 17.56 & 17.64 & 14.82 & 14.87 \\
\hline & 30/ 3 days & 15.69 & 15.57 & 12.93 & 13.02 \\
\hline \multicolumn{2}{|c|}{ L.S.D at 0.05} & 0.147 & 0.105 & 0.089 & 0.081 \\
\hline
\end{tabular}

\section{CONCLUSION}

It could be recommended to have highest and quality yield of sugar beet and sugar yield we must irrigate sugar beet crop 20 minutes every two days by using the drip irrigation with the Turbo emitter (long -path) in the soil at North Nile Delta. 


\section{REFERENCES}

Abo-Shady, Kh. A.; Samia, M. M. Hilal; E. El.M. El-Sheref and M.F.M Ibrahim (2010). Yield and quality of crop as affected by irrigation interval, cultivars and potassium fertilization in Northdelta. J. Agric. Res. Kafer El-Sheikh Univ., 36(4): 361-376.

Adekalu, K.O. and D.A. Okunade (2006). Effect of irrigation amount and tillage system on yield and water use efficiency of cowpea. Communication in Soil Sci. and Plant Analysis, 37, 225-228.

Ali, M. H.; M. R. Hoque; A. A. Hassan and A. Khair (2007). Effects of deficit irrigation on yield, water productivity, and economic returns of wheat. Agricultural Water Management 92 (3): 151-161.

Allen, R. G.; L. S. Pereirs; D. Raes and M. Smith (1998). Crop evapotranspiration. Guidelines for computing crop water requirements. FAO irrigation and drainage, paper No. 56, FAO, Rome.

Ancuta Puscas, E. Luca and A. Ceclan (2007). The effect of the climate and soil conditions sugar beet yield increase and stabilization in Transylvania's field conditions. Bulletin of University of Agricultural Sciences and Veterinary Medicine Cluj-Napoca. Horticulture, Vol. 64, No. 1-2.

Baigy, M. J., F. G. Sahebi., I. Pourkhiz, A. Asgari and F. Ejlali (2012). Effect of deficit-irrigation management on components and yield of sugar beet. Intl. J. Agron. Plant. Prod. Vol., 3 (S), 781-787, 2012

Byan, Usrya A.; M.Z. El-Shinawy; Hosnia, M. Gomaa and M.H. Mahmoud (2002). Yield and water relation of cowpea and pea plants as affected by water regime. Arab. Univ. J. of Agric. Sci., 10 (3), ISSN 1110-2675.

Chapman, H.D. and P.F. Pratt, (1961). Methods of analysis for soils, plants and waters. Univ. of California, USA. 
El-Maghraby, S.S.; M.A. Gomaa; I.F. Rehab and H.M.S. Hassan (2008). Response of sugar beet to some mechanical management practices, irrigation and plant densities. Sugar Tech. 10 (3): 219-226.

El-Nemr, M. K. (2010). Effect of operating pressure variation on uniformity parameters and its impact on crop productivity and power requirements of trickle irrigation. Misr J. of Agric. Eng. 27(4) : 1757-1770.

Ghadami Firouz Abadi A and M. Mirzaei, (2006). Effect of drip irrigation (tape) on the quantitative and qualitative characteristics of sugar beet, Journal of Research in Agronomy and Horticulture, No. 71, pp.11-6 .

Gomez, K.A and A. Gomez (1984). Statistical procedures for agricultural research. $1^{\text {st }}$ ed. John Wiley Sons, New Yourk.

Hansen, U. W.; O. W. Israelsen and Q. E. Stringharm (1979). Irrigation Principles and Practices. 4th (ed.). John Willey and Sons.

Hassanli, A.M.; S. Ahmadirad and S. Beecham (2010). Evaluation of the influence of irrigation methods and water quality on sugar beet yield and water use efficiency. Agricultural Water Management, 97: 357-362.

Ibrahim, M. M.; M.R. Khalifa; M.A. Korieb; F.I. Zein and E.H. Omer (2002). Yield and quality of sugar beet crop as affected by mid to late season drought and potassium fertilization of North Nile Delta. Egypt. J. Soil Sci., 42(1): 87-102.

Isoda, A.; H. Konishi and P. Wang (2007). Effect of different irrigation methods on yield and water use efficiency of sugar beet (Beta vulgaris) in the arid area of China. Hort. Research Chiba University (Japan). 61: 7-10.

Kayombo, B., T.E. Simalenga, and N. Hatibu, (2002). Effect of tillage methods on soil physical condition and yield of beans in a sandy 
loam soil. Agricultural Mechanization in Africa, Asia and Latin America, 33(4):15-18.

Keller J. and D. Karmeli (1974). Trickle irrigation design parameters. ASAE, 17 (4): 678-684.

Klute, A. (1986). Methods of Soil Analysis. Part 1. 2nd ed. ASA and SSSA. Madision. Wisconsin, USA.

Mc Ginnus, R.A. (1971). Sugar beet technology. $2^{\text {nd }}$ ed. Sugar beet development foundation, Fot. Collinos., Colo, USA .

Richter, G.M., K.W. Jaggard, R.A.C. Mitchell, (2001). Modelling radiation interception and radiation useefficiency for sugar beet under variable climatic stress. Agric. For. Meteorol. 109, 13-25.

Rinaldi M. and A. Vonella, (2006). The response of autumn and spring sown sugar beet (Beta vulgaris L.) to irrigation in Southern Italy: Water and radiation use efficiency. Field Crops Res. 95(3): 103114.

Rytter RM, (2005). Water use efficiency, carbon isotope discrimination and biomass production of two sugarbeet varieties under wellwatered and dry conditions. Journal of Agronomy and crop science.191(13)426-438.

Sepaskhah, A.R. and A.A. Kamgar-Haghighi, (1997). Water use and yields of sugar beet grown under every-other furrow irrigation with different irrigation intervals. Agric. Water Manage. 34, 71-79.

Tognetti, R.; M. Palladino; A. Minnocci; S. Delfine and A. Alvino (2003). The response of sugar beet to drip and low pressure sprinkler irrigation in southern Italy. Agric. Water. Manage. 60: 135-155.

Waller, R.A. and D.B. Duncan. (1969). Symmetric multiple Comparison Problem Amer. Stat. Assoc. Jour. December, 1485-1503.Zagazig J. Agric. Res., 19: 595-606. 


\section{الملخص العربى}

تأثير إدارة الري بالتنقيط على إنتاجية محصول بنجر السكر وبعض العلاقات

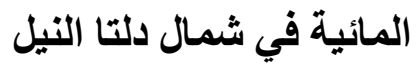

\section{محمد علي متولي'، عادل أحمد ماضىَّو الغباشي الثرنوبي العطويّ}

أجريت تجربتان حقليتان بالمزر عة البحثية بكلية الزر اعة بكفر الثيخ - جامعة كفر الثَيخ خـلال

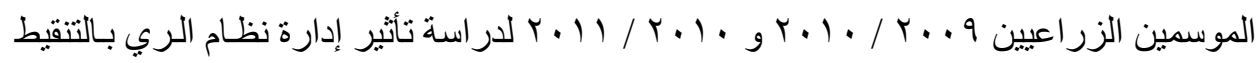
على إنتاجية محصول بنجر السكر ومكوناته وبعض العلاقات المائية في الأر اضي الطينية بشمال دلتا النيل، وقد صممت التجربة بنظـام القطع المنشقة مرة و احدة في أربـع مكررات حيث مثلت القطع الرئيسية ثناثة أنواع من النقاطـات و هي (Simple -orifice و و long -path in ) ب بينما شغلت القطع المنشقة فتر ات الري ممثلة في (الري لمدة ـ ـ دقيقة يومياً ـ الري لمدة • ب دقيقة كل يومين-و الري لمدة • ب دقيقة كل ثلاثة أيام) ، وكانت أهم نتائج الدر اسة كما يلي:-

ا ـ أوضحت النتائج أن معاملة الري بالتنقيط ذي النقاطات long -path حققت أعلي قيمـة

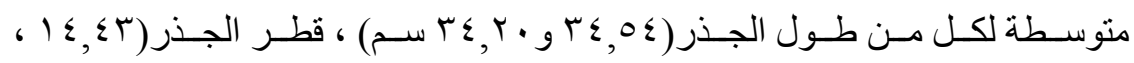

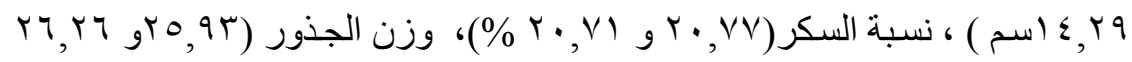

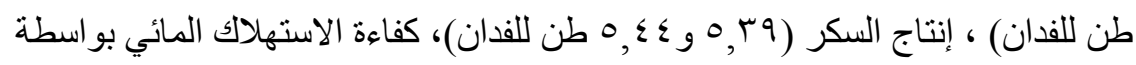

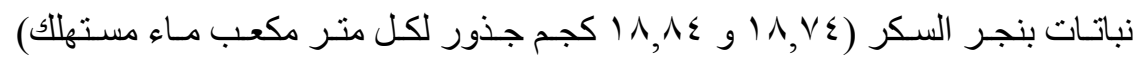

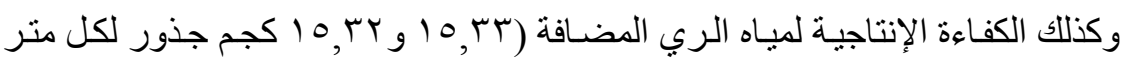

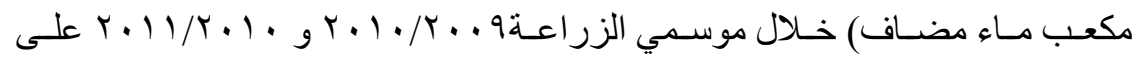

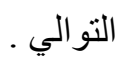

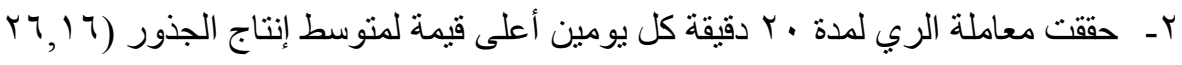

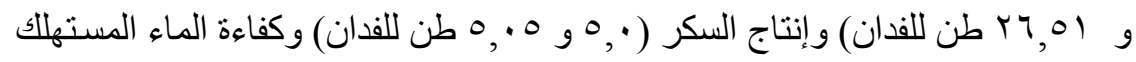

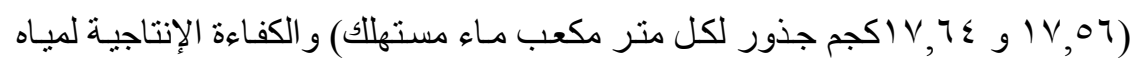

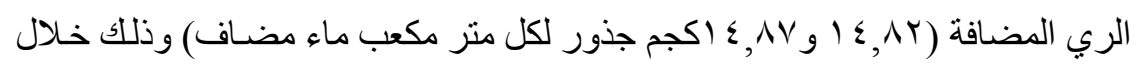

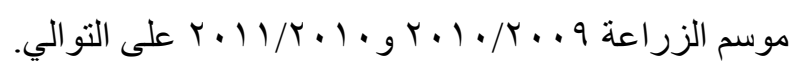

'معهد بحوث الهندسة الزراعية ـ مركز البحوث الزراعية ـ الجيزة ـ مصر

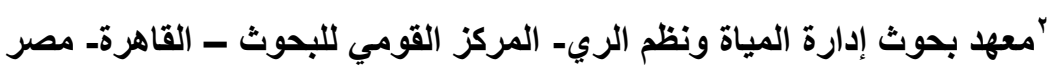

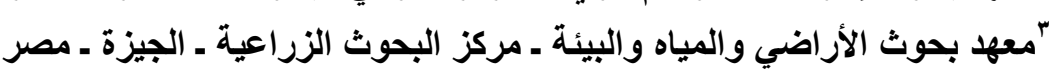




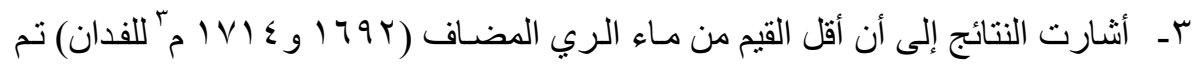

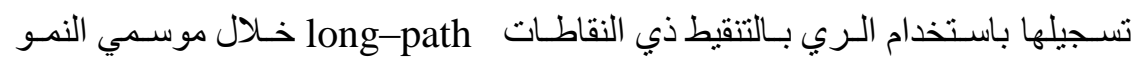

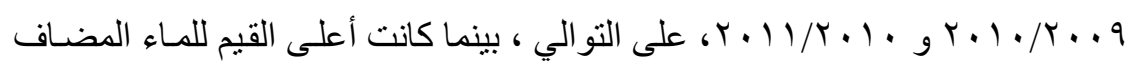

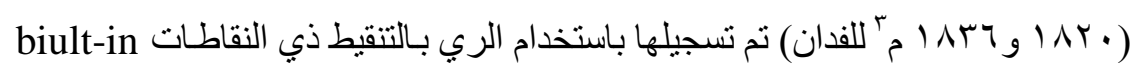

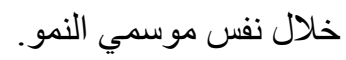
ع - أوضحت النتائج أن التفاعل بين أنو اع النقاطات و الفترة بين الريات أعطي أعلى القيم

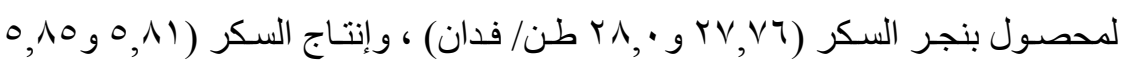

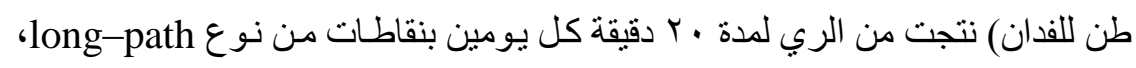

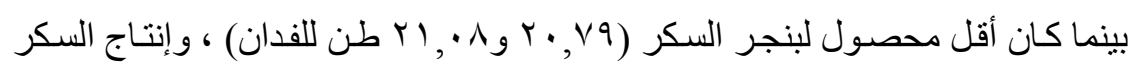

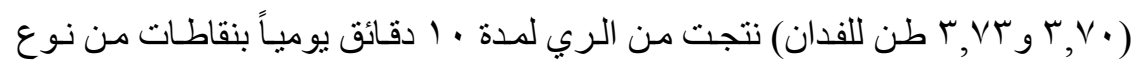

.Simple-orifice

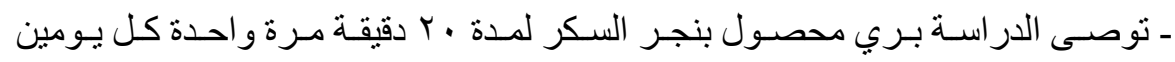

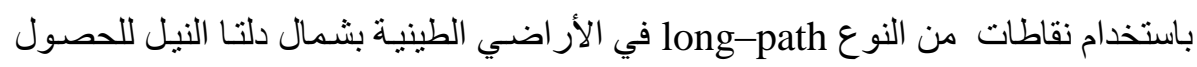
على أعلى إنتاجية من محصول بنجر السكر و السكر. 